\title{
The Impact of Margin Trading on China's Stock Market Liquidity
}

\author{
Jingjing Zhu*,Yongjian Zong \\ School of Economics and Management \\ NJUST \\ Nanjing, China \\ 18351874058@163.com
}

\begin{abstract}
Since securities margin trading has been started in China in 2010, it has promoted the diversification of securities trading in China. This article firstly combines the domestic and foreign existing researches to do a theoretical analysis of the impact of margin trading on the liquidity of China's stock market, and then selects the relevant data of Shanghai Securities 50 as a basis for the liquidity of the stock market. The influence of financing purchase amount and securities selling amount on the liquidity of SSE 50, to analyze the impact of margin trading on the liquidity of China's stock market.And then use the VAR model to study the effect of margin trading on the liquidity of China's stock market. The results show that the financing services can indeed improve the liquidity of the stock market, but the effect of securities lending on the liquidity of the stock market is not obvious. Finally, based on the results of the study, some suggestions are made for China's margin trading system.
\end{abstract}

Keywords-Margin; Liquidity; VAR

\section{INTRODUCTION}

Since the establishment of China's stock market in 1990, it has developed rapidly in recent years. The stock market has had an impact on corporate reforms, economic restructuring, and technological progress in China. Although the stock market has developed rapidly, there have been some drawbacks in its development. The main reason is that China's stock market has only a spot market at the beginning of the stock market, and the main investors are individual ones. Its trading model is also relatively simple, so it is very unstable in the early stage of development. So far, the development of China's stock market has been almost 30 years. The achievements made in China's economy occupy a very important position, and it is also an important part of China's socialist market economy.

Due to the late start of the development of China's securities market, the margin trading also developed later. Since the implementation of the margin trading in China's stock market in 2010, China's stock market has entered a new phase. The margin trading not only has developed very rapidly in recent years, but also has been valued by major securities companies. The majority of investors are very interested in margin trading. However, according to statistical data over the years, it is found that the scale of development of margin trading is not so balanced, and how the development of margin trading affects the liquidity of the stock market. This requires proof from empirical research to reach a conclusion. Therefore, this paper analyzes the impact of margin trading on the liquidity of the stock market through the empirical research on the influence of the amount of financing purchases and the amount of securities sold on the securities market in Shanghai stock market. The trading mechanism of margin trading puts forward policy recommendations to provide reference for the further development of China's stock market.

\section{LITERATURE REVIEW}

Karpoff and Lou (2010) found that margin financing investors are more sensitive to information on the stock market[1].Charoenrook and Daouk (2003) studied the 111 securities markets and found that the market with no bans on margin trading was significantly more liquid[2].

Deyong Yang and Qiong $\mathrm{Wu}$ (2011) used the data of China's stock market in Shanghai to conduct research. The margin trading mechanism can activate market transactions, increase market liquidity, and can inhibit changes in the company's stock price, which will help reduce corporate risks[3].However, Hongwei $\mathrm{Xu}$ and Xin Chen (2012) found that the impact of margin trading on the company's stock pricing efficiency is limited due to the research on the impact of the trial of margin financing and securities on the distribution pricing efficiency and yield ratio in China[4]. Mingyou He (2015) obtained an empirical study of the relevance of margin financing and short-term financing for earnings management, and concluded that margin financing and short-selling can effectively reduce the company's earnings management level[5]. Tingting Niu and Hailin Zhou (2011) used the Granger causality test and impulse response function analysis to find that the direction and intensity of the influence of financing transactions on the liquidity of the stock market depends on many factors. There exists between the stock market liquidity and financing transactions one-way causality[6].Yinggui Chen (2015) analyzed the two perspectives of individual stocks and the market and conducted an empirical study on the impact of the GEM. He concluded that financing transactions can improve the liquidity of the GEM to a certain extent in the short term, Securities Lending has a relatively small degree of influence[7].

Through the analysis of the above literatures, it has been found that both domestic and foreign researches have shown that the margin trading can have an impact on the liquidity of the stock market. As domestic data on margin trading are relatively small, domestic research mostly draws conclusions through factor analysis. The research on different markets and individual stocks shows that the margin trading can only affect 
the liquidity of the stock market and does not have the function of forecasting the stock price. The margin trading have a certain effect on effectively reducing the company's earnings management level.

\section{ThE CONCEPT OF MARGIN FINANCING AND MECHANISM ANALYSIS}

Margin trading refers to the act of an investor offering securities to a securities company that has qualifications for margin financing and securities lending, borrowing funds to buy securities (financing transactions) or borrowing securities and selling (short selling transactions). Including securities companies' financing of investors, securities lending and financial institutions' financing of securities companies and securities lending.

The margin trading mainly provides a mechanism for the liquidity of the stock market through the relationship between the supply and demand of the market. The implementation of the margin trading has increased the financing channels of investors, which in turn has increased the investment scope of investors. Therefore, the supply and demand of the stock market have increased, and the liquidity of the market has thus been improved. On the other hand, investors in investment in margin trading will no longer be limited by their own lack of funds. Investors can invest in financing, thereby increasing the supply and demand of the market and increasing the liquidity of the market.Since there are many reasons influencing the liquidity of the stock market in practice, such as market factors, policy adjustments, company decisions, and investors' willingness, and these reasons are difficult to verify and analyze through research, the article does not interpret these reasons one by one. The analysis and research of this article mainly focuses on the analysis of the impact of margin financing trading on the liquidity of the stock market.

\section{EMPIRICAL ANALYSIS OF EFFECT OF MARGIN TRADING ON THE LiQUidity OF THE STOCK MARKET}

\section{A. Sample Selection}

Because the constituent stocks contained in the Shanghai Composite Securities 50 are the most scientific and objective methods, the most representative 50 stocks with relatively large scale and good liquidity were selected in the Shanghai stock market. Moreover, the Shanghai Stock Exchange 50 also made its market performance of high-quality large-cap blue chips more accurate because of its better liquidity. Therefore, this paper selects SSE 50 as the representative of China's stock market, and describes the liquidity of the stock market through the ratio of daily turnover to intraday price changes. The size of the margin trading is expressed by the amount of stocks bought and the amount of securities sold in the Shanghai stock market. This paper selects a total of 238 data for the year of 2017 as a sample to study the effect of margin trading on the liquidity of the stock market.

\section{B. Indicator Definition}

\section{1) Liquidity Index (LIQ)}

$$
\mathrm{LIQ}=\mathrm{V}_{\mathrm{t}} /\left|\operatorname{InP}_{\mathrm{t} 1}-\mathrm{InP}_{\mathrm{t} 0}\right|
$$

As shown in (1) $\mathrm{P}_{\mathrm{t} 0}$ represents the opening price of $t, \mathrm{P}_{\mathrm{t} 1}$ represents the closing price of $t$, and $\mathrm{Vt}$ represents the turnover of $t$. The indicator describes liquidity through the trading volume required for price changes in the day, and the absolute value of the logarithmic difference between the logarithm of the t-day closing price and the opening price is used to express the intraday price change, and the daily interest generated can be excluded. Impact on the stock market.

2) Financing purchase amount $(F)$ : The purchase amount of financing transactions (F) refers to the total amount of stocks bought by the securities companies in the securities market within one trading day when the investors conduct financing transactions.

3) Securities sale amount (S): The securities sale amount (S) refers to the total amount of all the stocks sold by the securities company after borrowing securities from the securities company during each trading day.

\section{Stability Test}

When using the vector VAR model to empirically test time series, the prerequisite is that each variable must be stable, so we need to test the stability of each variable used before we conduct empirical analysis. Test the stationarity of the variables $\mathrm{L}, \mathrm{F}$, and $\mathrm{S}$. The test results are shown in Table I.

On the Table I, (c t $n$ ) c represents the intercept term, $t$ represents the trend term, and $\mathrm{n}$ is the lag order. Through the ADF test, the liquidity LnLIQ of the stock market, the logarithm value $\mathrm{LnF}$ of the financing purchase amount, and the $\mathrm{LnS}$ of the trading volume of the securities sale are all stable variables.

For the sake of research convenience, $\mathrm{L}=\mathrm{LnLIQ}$ is used to describe the stock market liquidity, $\mathrm{F}=\mathrm{LnF}$ to describe the amount of financing purchases, and $\mathrm{S}=\mathrm{LnS}$ to describe the amount of securities sold.

TABLE I. THE STATIONARITY OF VARIABLE

\begin{tabular}{|l|l|l|l|l|c|}
\hline $\begin{array}{c}\text { variabl } \\
\mathbf{e}\end{array}$ & \multicolumn{1}{|c|}{ Test } & \multicolumn{1}{c|}{ ADF } & \multicolumn{1}{c|}{$\mathbf{P}$} & $\mathbf{1 \%}$ & $\mathbf{5 \%}$ \\
\hline LnLIQ & (c 00$)$ & -14.079 & 0 & -3.4594 & -2.8738 \\
\hline LnF & (c 10$)$ & -4.1053 & 0.0001 & -3.9999 & -3.4300 \\
\hline LnS & (c 10$)$ & -4.5936 & 0.0101 & -3.9999 & -3.4300 \\
\hline
\end{tabular}

\section{Granger Relationship Test}

In order to better study the impact of margin trading on the liquidity of the stock market, we first use the Granger causality test to analyze the specific situations in which the financing and short selling transactions affect the liquidity of the stock market. Granger causality test results are shown in Table II.

According to the Granger causality test, under the 5\% significant condition, the refusal of financing purchases is not the original assumption of the Granger factor of liquidity in the stock market, and also rejects the original assumption that the stock market liquidity is not the Granger factor of the financing purchase amount. This shows that there is a two-way Granger causality between the amount of financing purchases and the liquidity of the stock market, that is, the amount of financing 
purchases can affect the liquidity of the stock market, and the liquidity of the stock market can also affect the amount of financing purchases.

TABLE II. GRANGER CAUSALITY TEST RESULTS

\begin{tabular}{|l|c|l|l|}
\hline \multicolumn{1}{|c|}{ hypothesis } & \multicolumn{1}{c|}{ P } & \multicolumn{1}{c|}{ F } & \multicolumn{1}{c|}{ conclusion } \\
\hline F is not L Grangerin & 0.00076 & 7.41515 & Refuse \\
\hline L is not F Grangerin & 0.00042 & 8.05045 & Refuse \\
\hline S is not L Grangerin & $5.0 \mathrm{E}-05$ & 10.3441 & Refuse \\
\hline L is not S Grangerin & 0.50896 & 0.67738 & Accept \\
\hline
\end{tabular}

However, under the 5\% significance condition, rejecting the liquidity of the stock market is not the original assumption of the Granger factor that causes the selling amount of the securities, but it cannot reject the null hypothesis that the selling amount of the securities is not the Granger factor of the stock market liquidity. This shows that there is a one-way Granger causality between the selling of securities securities and the liquidity of the stock market, that is, the amount of financing sales can affect the liquidity of the stock market, but the stock market liquidity cannot affect the amount of securities sold.

\section{E. Analysis of the Effect of Financing Services on the}

Liquidity of Stock Market Based on VAR Model

1) The influence of financing services on the level of chinese stock market's flow

a) Establish a VAR model between the financing buy-in $(F)$ and the stock market liquidity $(L)$ :

$$
\begin{aligned}
& \mathrm{L}_{\mathrm{t}}=\alpha_{0}+\alpha_{1} \mathrm{~L}_{\mathrm{t}-1}+\ldots+\alpha_{\mathrm{p}} \mathrm{L}_{\mathrm{t}-\mathrm{p}}+\beta_{1} \mathrm{~F}_{\mathrm{t}-1}+\ldots+\beta_{\mathrm{r}} \mathrm{F}_{\mathrm{t}-\mathrm{r}}+\varepsilon_{\mathrm{t}} \\
& \mathrm{F}_{\mathrm{t}}=\alpha_{0}+\alpha_{1} \mathrm{~F}_{\mathrm{t}-1}+\ldots+\alpha_{\mathrm{p}} \mathrm{F}_{\mathrm{t}-\mathrm{p}}+\beta_{1} \mathrm{~L}_{\mathrm{t}-1}+\ldots+\beta_{\mathrm{r}} \mathrm{L}_{\mathrm{t}-\mathrm{r}}+\varepsilon_{\mathrm{t}}
\end{aligned}
$$

TABLE III. VAR MODEL LLC TESTS FOR F AND L

\begin{tabular}{|l|l|l|l|l|}
\hline lag & \multicolumn{1}{|c|}{ logl } & \multicolumn{1}{|c|}{ AIC } & SC & DRC \\
\hline 1 & -330.7809 & 2.842033 & 2.929832 & 0.055891 \\
\hline 2 & -319.9804 & 2.796444 & 2.943217 & 0.051609 \\
\hline 3 & -314.6881 & 2.797345 & 3.003448 & 0.049909 \\
\hline 4 & -310.0552 & 2.803891 & 3.069685 & 0.048523 \\
\hline
\end{tabular}

b) Determine the lag order: The second-order lag model was selected based on the judgment of the AIC standard in the LLC test results,as shown in table III.

c) Model results and analysis: The OLS estimation is performed on the VAR equation in (2) to obtain the estimated value of financing purchase (F) and stock market liquidity (L), as shown in Table IV.

According to the results of the equations and the results shown in Table IV, the effect of the amount of financing purchases on the liquidity of the stock market is positive, and when the second period lags, it has a more significant effect, and at the same time, the stock market liquidity is also subject to its own lag value. The influence is positive. In the second estimation equation, the current financing purchase amount is the explained variable, the liquidity lag value and the lagged value of the financing purchase amount are the explanatory variables. According to the equation and the results shown in Table IV, the stock market liquidity is used to buy the financing. The amount has a positive effect, but it is less obvious in the second period. However, the purchase amount of financing is affected by its own lag value, and the most obvious effect is the first period. After analysis, it can be concluded that financing transactions have a certain effect on the improvement of stock liquidity.

TABLE IV. L AND F OLS ESTIMATION RESULTS

\begin{tabular}{|l|l|l|}
\hline & liquidity $(\mathbf{L})$ & \multicolumn{1}{|c|}{ Financing purchase amount $(\mathbf{F})$} \\
\hline $\mathrm{L}(-1)$ & $\begin{array}{l}0.060281 \\
(0.94448)\end{array}$ & $\begin{array}{l}0.044624 \\
(3.93552)\end{array}$ \\
\hline \multirow{2}{*}{$\mathrm{L}(-2)$} & $\begin{array}{l}0.156388 \\
(2.37292)\end{array}$ & $\begin{array}{l}0.004956 \\
(0.42325)\end{array}$ \\
\hline \multirow{2}{*}{$\mathrm{F}(-1)$} & $\begin{array}{l}0.011912 \\
(0.03258)\end{array}$ & $\begin{array}{l}0.731185 \\
(11.2567)\end{array}$ \\
\hline \multirow{2}{*}{$\mathrm{F}(-2)$} & $\begin{array}{l}0.605410 \\
(1.70345)\end{array}$ & $\begin{array}{l}0.149605 \\
(2.36942)\end{array}$ \\
\hline \multirow{2}{*}{$\mathrm{C}$} & 1.010565 & 1.944228 \\
& $(0.26136)$ & $(2.83036)$ \\
\hline
\end{tabular}

2) The impact of securities lending on the Level of Liquidity in China's Stock Market: Next, using the same analytical ideas as above, we analyze the effect of securities lending on the level of Chinese stock market liquidity.

a) Establish a VAR model between the securities sale (S) and the stock market liquidity $(L)$

$$
\begin{aligned}
& \mathrm{L}_{\mathrm{t}}=\alpha_{0}+\alpha_{1} \mathrm{~L}_{\mathrm{t}-1}+\ldots+\alpha_{\mathrm{p}} \mathrm{L}_{\mathrm{t}-\mathrm{p}}+\beta_{1} \mathrm{~S}_{\mathrm{t}-1}+\ldots+\beta_{\mathrm{r}} \mathrm{S}_{\mathrm{t}-\mathrm{r}}+\varepsilon_{\mathrm{t}} \\
& \mathrm{S}_{\mathrm{t}}=\alpha_{0}+\alpha_{1} \mathrm{~S}_{\mathrm{t}-1}+\ldots+\alpha_{\mathrm{p}} \mathrm{S}_{\mathrm{t}-\mathrm{p}}+\beta_{1} \mathrm{~L}_{\mathrm{t}-1}+\ldots+\beta_{\mathrm{r}} \mathrm{L}_{\mathrm{t}-\mathrm{r}}+\varepsilon_{\mathrm{t}}
\end{aligned}
$$

TABLE V. VAR MODEL LLC TESTS FOR S AND L

\begin{tabular}{|l|l|l|l|l|}
\hline lag & \multicolumn{1}{|c|}{ logl } & AIC & SC & DRC \\
\hline 1 & -470.6769 & 4.022590 & 4.110389 & 0.181991 \\
\hline & & & & \\
\hline 2 & -462.1042 & 4.000883 & 4.147655 & 0.172111 \\
\hline 3 & -456.9911 & 4.008435 & 4.214538 & 0.167551 \\
\hline 4 & -450.9814 & 4.008388 & 4.274182 & 0.161829 \\
\hline
\end{tabular}

b) Determine the lag order: The second-order lag model was selected based on the judgment of the AIC standard in the LLC test results, as shown in tableV.

c) Model results and analysis: The OLS estimation is performed on the VAR equation in (3) to obtain the estimated results of the securities sale (S) and stock market liquidity (L), as shown in Table VI.

According to the equation and the regression result in table VI, the lag value of the stock market liquidity is positive, but only in the second period, the lag in the first-phase lags in the securities sell-off amount to the stock market liquidity. The 
impact is positive and obvious. The explanatory variable of the second equation is the current value of the sell-sell securities, and the explanatory variable is the lag value of the stock market liquidity and the lagged value of the securities sell-off. According to the analysis of the regression results of the equations and Table VI, the lag value of the securities selling amount has a positive effect on the current securities selling amount, and it is more obvious in the first period, but the lag value of the stock market liquidity is short-selling. Selling volume has no significant effect. Through the analysis, it is concluded that the securities selling amount has a certain effect on the improvement of stock liquidity, but the effect is not obvious.

TABLE VI. L AND S OLS ESTIMATION RESULTS

\begin{tabular}{|l|l|l|}
\hline & \multicolumn{1}{|c|}{ liquidity $(\mathbf{L})$} & \multicolumn{1}{|c|}{ Securities selling amount $(\mathbf{S})$} \\
\hline $\mathrm{L}(-1)$ & 0.041817 & 0.025123 \\
& $(0.64488)$ & $(1.16004)$ \\
\hline $\mathrm{L}(-2)$ & 0.122019 & -0.003546 \\
& $(1.89904)$ & $(-0.16522)$ \\
\hline $\mathrm{S}(-1)$ & 0.252870 & 0.830863 \\
& $(1.28941)$ & $(12.6851)$ \\
\hline $\mathrm{S}(-2)$ & -0.077314 & 0.150162 \\
& $(-0.39272)$ & $(2.28378)$ \\
\hline $\mathrm{C}$ & 14.17176 & -0.068940 \\
& $(08.46200)$ & $(-0.12325)$ \\
\hline
\end{tabular}

\section{Discussion Of Research Results AND Policy RECOMMENDATIONS}

\section{A. Research Result}

The development of margin financing and securities lending business has existed for more than ten years. Although it has developed rapidly under the continuous efforts of our country, there will be some problems and deficiencies in it. Through the study of this paper, draw the conclusion:

According to the empirical analysis results, it shows that financing transactions have a more obvious impact on the liquidity of the stock market, and the securities lending transaction is less obvious. This is because the margin trading has been implemented in China since the introduction of margin trading. All aspects are developing very rapidly, but the scale of the securities lending is still relatively small relative to the scale of financing. This makes the development of China's margin trading unbalanced, and therefore their effect on the stock market is different. This may be related to the preferences of Chinese investors and the policy of margin financing and short selling.financing services and securities lending all have a positive effect on the liquidity of China's stock market, so the development of margin trading in China can improve the liquidity of the stock market.In addition, the study found that the size of the liquidity of the stock market is affected by its own lag value, in addition to the amount of financing purchases and the amount of securities sold.

\section{B. Policy Suggestion}

Through empirical research, this paper concludes that margin trading can improve the liquidity of China's stock market and have a positive effect on its development. Therefore, the following suggestions are made for the development of margin financing in China's stock market:China needs to further promote the margin trading, improve the unbalanced development of China's margin trading, and enable the margin trading to give full play to its role in the stock market.Further publicize the margin trading and change investors' investment ideas. Some investors in China still do not have enough knowledge of the margin trading to accept this investment model. Therefore, we should actively promote the basic knowledge of margin trading so that more investors can correctly understand the business and transform investment. Appropriately reduce investors' restrictions on margin trading.Compared with foreign countries, the entry threshold for China's margin trading markets is relatively high, which makes some investors unable to conduct margin trading, reducing the investor's enthusiasm for participation in investment, and limiting the expansion of margin trading. For example, the threshold for general investors to conduct margin trading systems is that personal asset accounts are greater than 500,000 and account opening is 18 months. These restrictions are relatively high for general investors, and regulators can meet effective regulatory requirements. Next, the investor's entry threshold and the related margin ratio should be appropriately reduced.

This article also has some deficiencies. There are many reasons that affect the liquidity of the stock market in the actual market, such as market factors, policy adjustments, company decisions, and investors' willingness. Because the data for these reasons is difficult to obtain and it is also very difficult to research and verification, so this article does not analyze these reasons.But these issues are worth further study.

\section{REFERENCE}

[1] J. M. Karpoff and X.X. Lou, "Short Sellers and Financial Misconduct," The Journal of Finance, vol. ED-65, May 2010.

[2] A. Charoenrook and H. Daouk, The World Price of ShortSelling, Working PaPer, The OWen Graduate School of Management, Vanderbilt University, 2003.

[3] D.Y. Yang and Q. Wu, "Empirical analysis of the influence of margin financing and securities lending on the Shanghai securities market: Based on the perspective of liquidity and volatility," Journal of Central University of Finance and Economics, vol. ED-5, pp. 28-34, 2011.

[4] H.W. Xu and X. Chen, "Does the introduction of margin trading in China promote the pricing efficiency of the underlying stocks? Empirical Research Based on Double Difference Model," Management World, vol. ED-5, pp. 52-61, 2012.

[5] M.Y. He, "Research on the Earnings Management of Listed Companies in China under the Background of Margin and Short Selling," Finance and Accounting Monthly, vol. ED-30, pp. 46-50, 2015.

[6] T.T. Niu and H.L. Zhou, "Empirical Study on the Impact of Financing Warrants on the Liquidity of China's Stock Market," Journal of Shanghai University of Commerce, vol. ED-5, pp. 79-84, 2011.

[7] Y.G. Chen, The effect of margin financing and securities lending on the volatility and liquidity of China's GEM., Huaqiao University, 2015. 